\title{
NOTHOFAGUS BETULOIDES (MIRB.) OERST 1871 (FAGALES: NOTHOFAGACEAE) FORESTS IN SOUTHERN PATAGONIA AND TIERRA DEL FUEGO
}

\author{
BOSQUES DE NOTHOFAGUS BETULOIDES (MIRB.) OERST 1871 (FAGALES: \\ NOTHOFAGACEAE) EN LA PATAGONIA AUSTRAL Y TIERRA DEL FUEGO
}

\author{
Alvaro Promis ${ }^{1}$, Gustavo Cruz ${ }^{2}$, Albert Reif ${ }^{1}$, Stefanie Gärtner ${ }^{3}$ \\ "... for in these still solitudes, Death, instead of Life, seemed the predominant spirit (Darwin 1839)"
}

\section{THE GENUS Nothofagus}

Southern Patagonia and Tierra del Fuego have always been of great interest for botanists because of their evergreen plant formations and biogeographical perspectives. Antarctic families like the Winteraceae and genera like Gunnera and Gaultheria represent the ancient Gondwana flora. The biogeography of Nothofagus, the southern beech, has been the classical study that supports the sequence of Gondwana break-up and the linkage of the Austral biota between South America and Australasia (Swenson et al. 2001).

In the past the genus Nothofagus was included in the Fagaceae family (Rodríguez \& Quezada 2003), and seemed to be closely related to Fagus (Hill \& Dettmann 1996). More recent genetic studies have shown that the genus of Nothofagus belongs to a new monogeneric family, the Nothofagaceae (Hill \& Jordan 1993; Hill \& Dettmann 1996; Manos 1997; Jordan \& Hill 1999).

There are currently 36 recognised Nothofagus species (Table 1), 26 of which occur in Australasia and the remaining 10 in South America. Of the total number, $78 \%$ are evergreen and $22 \%$ deciduous. The evergreen Nothofagus species can grow equally well at tropical latitudes in the mountains of New Guinea (13 species: van Royen 1983), and in subantarctic areas. Nothofagus betuloides (Mirb.) Oerst is the species with the southernmost distribution. However, natural hybridisation between evergreen Nothofagus species has been demonstrated in South America (Donoso \& Atienza 1983; Donoso et al. 2004) as well as in New Zealand (Wardle 1984).

\footnotetext{
1 Institute of Silviculture, Faculty of Forest and Environmental Sciences, University of Freiburg, Tennenbacher Str. 4, D-79085 Freiburg, Germany*.

2 Department of Silviculture, Faculty of Forest Sciences, University of Chile, Santa Rosa 11315, La Pintana, Casilla 9206, Santiago, Chile.

3 Department of Renewable Resources, University of Alberta, Edmonton, Alberta, T6G 2H1, Canada.

* Corresponding author. Tel.: 0049761203 8622; Fax: 0049761203 3781. alvaro.promis@waldbau.uni-freiburg.de
} 
TABLE 1. Distribution and leaf characteristics of the Nothofagus species.

\begin{tabular}{|c|c|c|c|c|c|}
\hline Species & Distribution & Leaves & Species & Distribution & Leaves \\
\hline \multicolumn{3}{|l|}{ Brassospora } & \multicolumn{3}{|l|}{ Fuscospora } \\
\hline N. aequilateralis & New Caledonia & Evergreen & N. alessandri & Chile & Deciduous \\
\hline N. balansae & New Caledonia & Evergreen & N. fusca & New Zealand & Evergreen \\
\hline N. baumanniae & New Caledonia & Evergreen & N. gunnii & Australia & Deciduous \\
\hline N. brassii & New Guinea & Evergreen & N. solandri & New Zealand & Evergreen \\
\hline N. carrii & New Guinea & Evergreen & N. truncata & New Zealand & Evergreen \\
\hline N. codonandra & New Caledonia & Evergreen & \multicolumn{3}{|l|}{ Lophozonia } \\
\hline N. crenata & New Guinea & Evergreen & N. alpina & Chile - Argentina & Deciduous \\
\hline N. discoidea & New Caledonia & Evergreen & N. cunninghamii & Australia & Evergreen \\
\hline N. flaviramea & New Guinea & Evergreen & N. glauca & Chile & Deciduous \\
\hline N. grandis & New Guinea & Evergreen & N. macrocarpa & Chile & Deciduous \\
\hline N. nuda & New Guinea & Evergreen & N. menziesii & New Zealand & Evergreen \\
\hline N. perryi & New Guinea & Evergreen & N. moorei & Australia & Evergreen \\
\hline N. pseudoresinosa & New Guinea & Evergreen & N. obliqua & Chile - Argentina & Deciduous \\
\hline N. pullei & New Guinea & Evergreen & \multicolumn{3}{|l|}{ Nothofagus } \\
\hline N. resinosa & New Guinea & Evergreen & N. antarctica & Chile - Argentina & Deciduous \\
\hline N. rubra & New Guinea & Evergreen & N. betuloides & Chile - Argentina & Evergreen \\
\hline N. starkenborghii & New Guinea & Evergreen & N. dombeyi & Chile - Argentina & Evergreen \\
\hline N. stylosa & New Guinea & Evergreen & N. nitida & Chile & Evergreen \\
\hline N. womersleyi & New Guinea & Evergreen & N. pumilio & Chile - Argentina & Deciduous \\
\hline
\end{tabular}

Source: Hill \& Dettmann (1996); Ogden et al. (1996); Read \& Brown (1996); Read \& Hope (1996); Rodríguez \& Quezada (2003)

2. Nothofagus betuloides - the southernmost evergreen tree species and its forests

$N$. betuloides is known commonly as 'coihue de Magallanes' in Chile and 'guindo' in Argentina. It was also well known to the Indian tribes of South America who referred to it as coigüe (Mapuche name), yerkianop (Alacaluf name), ouchpaya (Ona or Shelknam name), and shushchi (Yahgan or Yamana name).

\subsection{Biology}

$N$. betuloides is one of the longest-living South American Nothofagus species, with specimens reaching 500-600 years of age (Veblen et al. 1996) or more (628 years: Gutiérrez et al. 1991). The trees (Fig. 1) can grow to heights of $20 \mathrm{~m}$, and in a few cases up to $35 \mathrm{~m}$, but can also remain as only meter low shrubs in subantarctic shrublands. The trunk can reach $2 \mathrm{~m}$ in diameter. The bark is grey or reddish in colour and relatively smooth. The twigs are puberulent, rarely glabrous. The leaves (12-28 x 8-18 mm) are ovate-elliptical to elliptical-suborbicular, acute to obtuse, cuneate at the base, serrate, subcoriaceous, glabrous (Fig. 2) (Moore 1983).

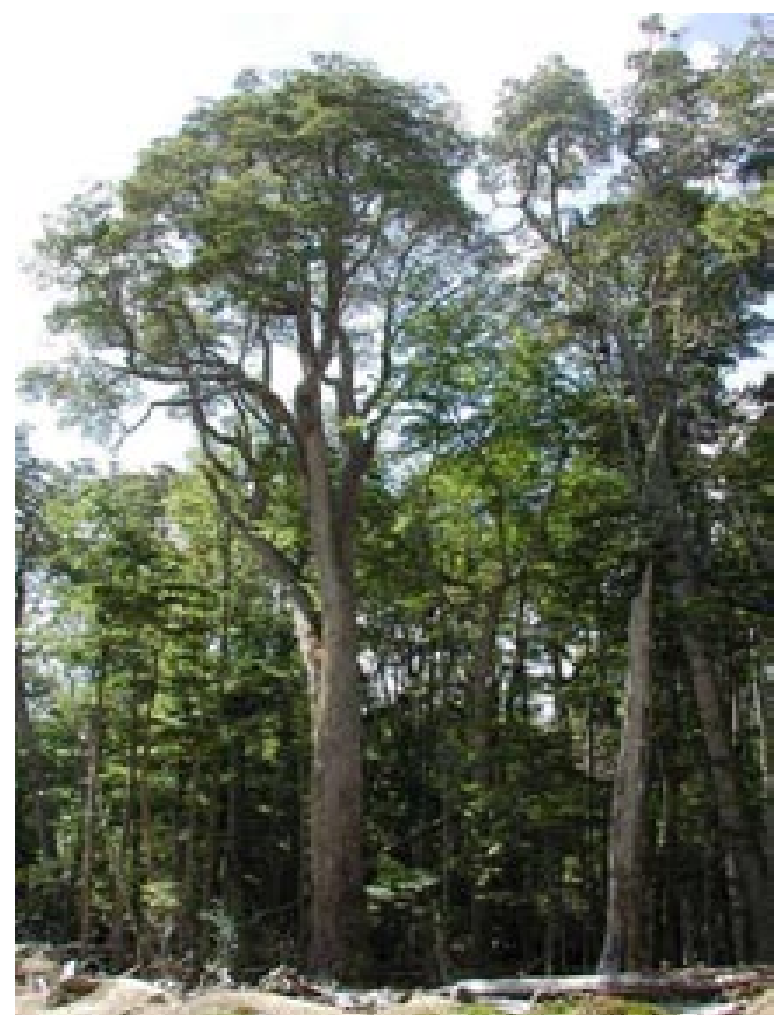

Fig. 1. Nothofagus betuloides growing in Río Bueno, Tierra del Fuego (Photo: A. Promis). 


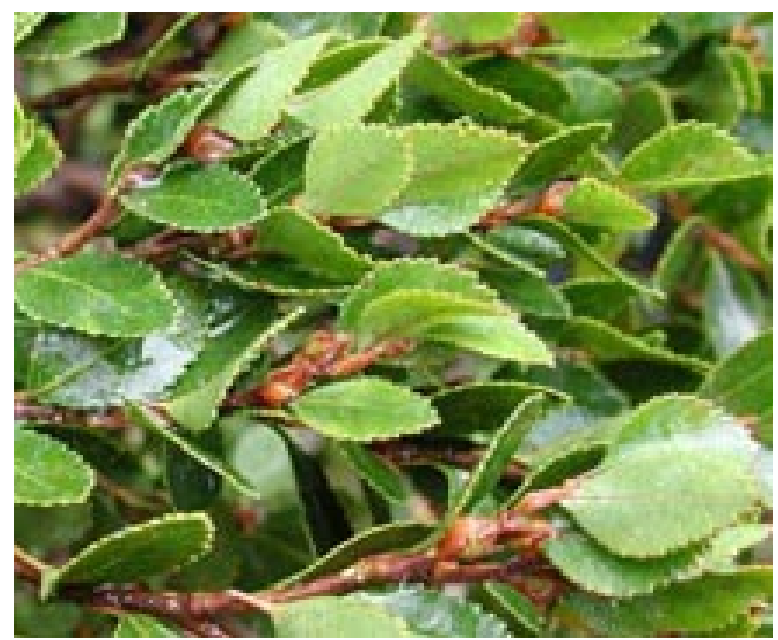

Fig. 2. Leaves and seeds of Nothofagus betuloides (Photo: A. Promis)

$N$. betuloides is a hermaphrodite. The male flowers are solitary, with a perianth $4-4.5 \mathrm{~cm}$ long, 5-7 lobes, and has 10-16 stamens. Female flowers occur in groups of three (Moore 1983; Rodríguez \& Quezada 2003). Depending on the location, N. betuloides flowers between September and December (Rodríguez \& Quezada 2003). However, the South American Nothofagus species do not flower regularly and in some years widespread non-flowering occurs, and seed production is therefore intermittent (Báez et al. 2002).

The fruits of $N$. betuloides (Figs. 2 and 3) are nuts occurring in threes, 5-6 x 4-4.5 mm, triquetrous, glabrous; cupule 4-partite (Moore 1983). They mature during summer and are dispersed mainly by gravity and wind between March and May (Donoso \& Donoso 2007; Ibarra et al. 2007). Although nut development in Nothofagus is often close to 100 $\%$, the majority of the seeds produced are often not viable (Báez et al. 2002).

The wood of $N$. betuloides has a slight lustre, and a fine and homogeneous texture. The grain is generally straight. The growth rings are annual but not clearly visible. The sapwood has a yellowish-white colour, and the heartwood is light pink to reddish-brown. The wood density has been classified as low, with a basic density of $615 \mathrm{~kg} \mathrm{~m}^{-3}$, and an air dry density of $620 \mathrm{~kg} \mathrm{~m}^{-3}$. With respect to the strength properties of the species, the wood has a low modulus of rupture $\left(708 \mathrm{~kg} \mathrm{~cm}^{-2}\right)$, a medium modulus of elasticity $\left(103 \mathrm{t} \mathrm{cm}^{-2}\right)$, and also a

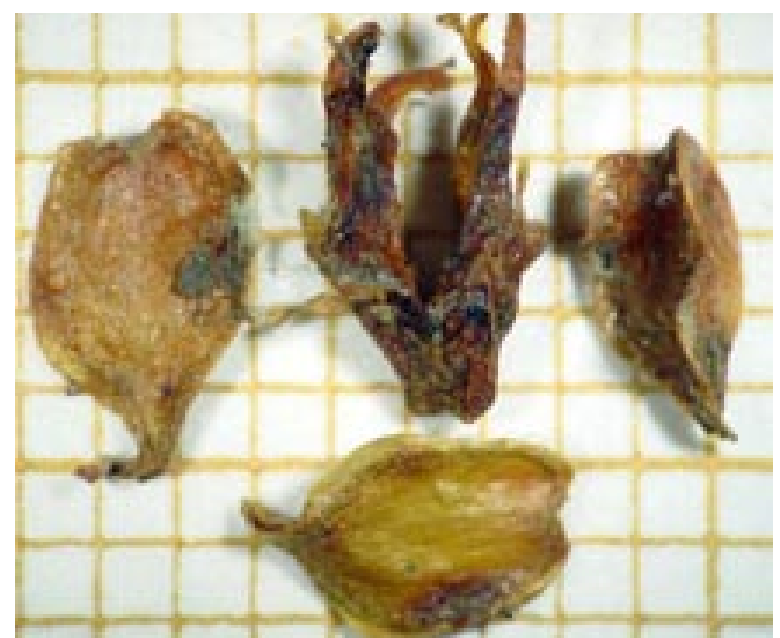

Fig. 3. Seeds of Nothofagus betuloides (Photo: G. Cruz)

medium maximum crushing strength parallel to the grain when dry $\left(445 \mathrm{~kg} \mathrm{~cm}^{-2}\right.$ ) (Pérez 1983; Manso et al. 2007). The wood is long lasting, even without treatment. The durability ranges from durable to very durable when it is not exposed to conditions promoting rapid decay, e.g., ground contact (Donoso \& Donoso 2007).

The timber can be used as poles, flooring, indoor panelling, roofing (joist and rafter), pillars, furniture, decorative veneers and panels (Pérez 1983; Manso et al. 2007).

\subsection{Ecology}

\subsubsection{Geographical distribution}

$N$. betuloides is an endemic tree species of the Chilean and Argentinean subantarctic forests. In Chile it occurs from the Valdivia district $\left(40^{\circ}\right.$

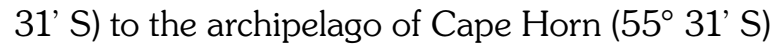
(Rodríguez \& Quezada 2003). In Argentina it occurs mainly between $48^{\circ} \mathrm{S}$ to the southernmost tip of Tierra del Fuego (Veblen et al. 1996) (Fig. 4).

In the northern part of its distribution, $N$. betuloides grows at high elevations in both the coastal (above $800 \mathrm{~m}$ a.s.l.) and the Andean Cordillera (above $900 \mathrm{~m}$ a.s.l.), approaching the treeline. In the south it forms forests in elevations from sea level to upper treeline on the southern and western sides of Tierra del Fuego (McQueen 1976; Tuhkanen et al. 1989-1990; Donoso \& Donoso 2007). 


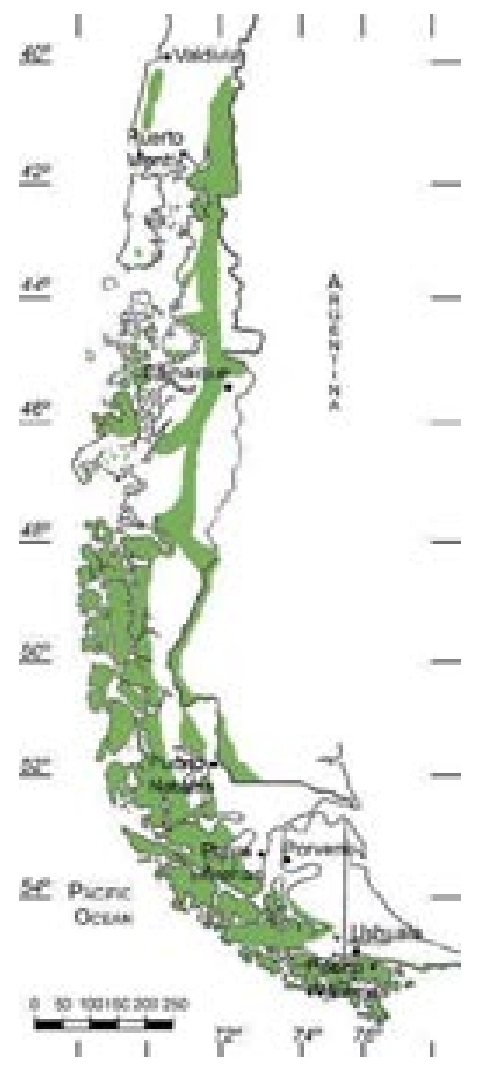

Fig. 4. Map of the distribution of Nothofagus betuloides in Chile and Argentina (Source: Dimitri 1972; Ibarra et al. 2007).

\subsubsection{Autecology: Germination \\ and juvenile growth}

Germination is epigeous and occurs during the spring of the year in which the seed is produced (Donoso \& Donoso 2007). Most Nothofagus species do not develop a persistent seed bank (Veblen et al. 1996). Germination can occur in sunny, semi-shady or shady places (Roig et al. 1985). The seed dormancy of $N$. betuloides is readily broken (Martínez Pastur et al. 1994). Pre-germinative treatments have demonstrated that with a cold-moist stratification of the seeds for a period of up to 120 days the germination rate reaches up to $45 \%$ (Donoso \& Donoso 2007). The immersion of seeds in $100 \mathrm{ppm}$ giberelic acid for 12 hours results in a germination rate of $33 \%$. The application of potassium nitrate has no effect (Martínez Pastur et al. 1994).

The natural regeneration of $N$. betuloides is through seed. Vegetative reproduction by means of sprouting at the base of the trunks of living trees has also been observed on the upper slopes of Tierra del Fuego, where the trees are stunted and crooked (Krummholz) (Gutiérrez et al. 1991).

For all Nothofagus species in South America, seedling establishment occurs best under moderately high light levels and where bare mineral soil has been exposed (Veblen et al. 1996). For example, $N$. betuloides is able to grow as a pioneer species on open sites with mineral soils, including moraines (Armesto et al. 1992), recently deglaciated areas (Pisano 1978), and forest road banks. In old-growth forests, seedlings often establish on fallen logs (Roig et al. 1985; Veblen et al. 1996).

Positive rates of net photosynthesis of up to three hours (around noon) have been reported for $N$. betuloides seedlings growing under a closed canopy in Tierra del Fuego, and up to ten hours in canopy gaps (Squeo \& Cabrera 1995; Arroyo et al. 1996). As $N$. betuloides has a relatively low light compensation point for net positive photosynthesis, seedlings can establish under closed canopy conditions. $N$. betuloides can form an abundant stock of persistent seedlings or saplings, surviving in the understorey for many decades and even exceeding one hundred years (Rebertus \& Veblen 1993a; Veblen et al. 1996) at high elevations or latitudes, where there is little competition from ground flora.

The relationship between foliar weight and leaf area is on average lower for seedlings growing in shade $\left(9.3 \mathrm{mg} \mathrm{cm}^{-2}\right)$ than for those situated in canopy gaps ( $11 \mathrm{mg} \mathrm{cm}^{-2}$ ). The foliar nitrogen concentration of the seedlings is similar under both light conditions (ca. $1.2 \%$ : Squeo \& Cabrera 1995).

\subsubsection{Synecology: Vegetation types}

$N$. betuloides forests have been well described phytogeographically, and given the following designations: subantarctic evergreen forest (Skottsberg 1910; Godley 1960), subantarctic evergreen rain forest (Schmithüsen 1956), Nothofagetum betuloidis (Oberdorfer 1960; Pisano 1977), evergreen forest (Pisano 1977; Moore 1983; Pisano 1997), $N$. betuloides forest type (Donoso 1981; Veblen et al. 1983), sub-region of the microphyllus evergreen forest (Gajardo 1994), and Andean and coastal temperate evergreen forest (Luebert \& Pliscoff 2006).

$N$. betuloides forests are predominantly found where an oceanic cold temperate climate prevails, characterised by a mean temperature of around $8.9^{\circ} \mathrm{C}$ in the warmest month (between 8.5 and 
$10^{\circ} \mathrm{C}$ ) and $2.7^{\circ} \mathrm{C}$ in the coldest (between 1.0 and $\left.3.5^{\circ} \mathrm{C}\right)$. The rainfall ranges between $800-2,000 \mathrm{~mm}$ year ${ }^{-1}$; i.e., there are no arid months (Pisano 1977, Tuhkanen 1992). The climate of the mixed evergreen - deciduous forest is less oceanic, characterised by a mean temperature between 9.0 to $9.5^{\circ} \mathrm{C}$, and even $11^{\circ} \mathrm{C}$, in the warmest month, and between 0.5 to $2.5^{\circ} \mathrm{C}$ in the coldest month (Tuhkanen 1992). $N$. betuloides can also grow as creeping shrub in transition to the tundra near the Pacific Ocean. The climate there has a mean temperature of $8.8^{\circ} \mathrm{C}$ in the warmest and $4.4^{\circ} \mathrm{C}$ in the coldest month. The rainfall exceeds $2,000 \mathrm{~mm}^{-1}$ year $^{-1}$, and reaches up to 4,846 $\mathrm{mm}_{\text {year }}{ }^{-1}$ (McQueen 1976; Pisano 1977; Pisano 1981).

The climate conditions, where the pure evergreen $N$. betuloides forest and the mixed evergreen forests are found, until now are only poorly known. Nonetheless, we hypothesize that the temperature would be affecting the distribution of the tree species in these forests, with mild winters adjacent to the sea and at low elevations, and decreasing minimum temperatures further inland.

In southern Patagonia and Tierra del Fuego, four characteristic forest types dominated by $N$. betuloides, and additionally occurrences in subantarctic shrublands, can be distinguished: (1) the pure evergreen $N$. betuloides forest, (2) the mixed evergreen $N$. betuloides - Drimys winteri J.R. et Forster 1775 forest, (3) the mixed evergreen $N$. betuloides - D. winteri - Pseudopanax laetevirens (C. Gay) Seem. 1894 forest, and (4) the mixed evergreen - deciduous N. betuloides - Nothofagus pumilio (Poepp. et Endl.) Krasser 1896 forest (Pisano 1977). (5) Outside closed forests, N. betuloides is able to grow as creeping shrub in subantarctic Krummholz formations and moorland.

(1) Pure evergreen $N$. betuloides forest is mainly located in inland southern Patagonia and Tierra del Fuego, and also at the treeline in some places protected from strong winds (Fig. 5).

Two soil formation processes have been described for pure $N$. betuloides forests, podsolisation on well-drained sites and hydromorphism in areas with moderate to high waterlogging (Pisano 1977; Puigdefábregas et al. 1999; Gerding \& Thiers 2002; Romanyà et al. 2005). These soils are normally shallow $(<50 \mathrm{~cm})$, loamy in texture, acidic ( $\mathrm{pH} 3.4-$

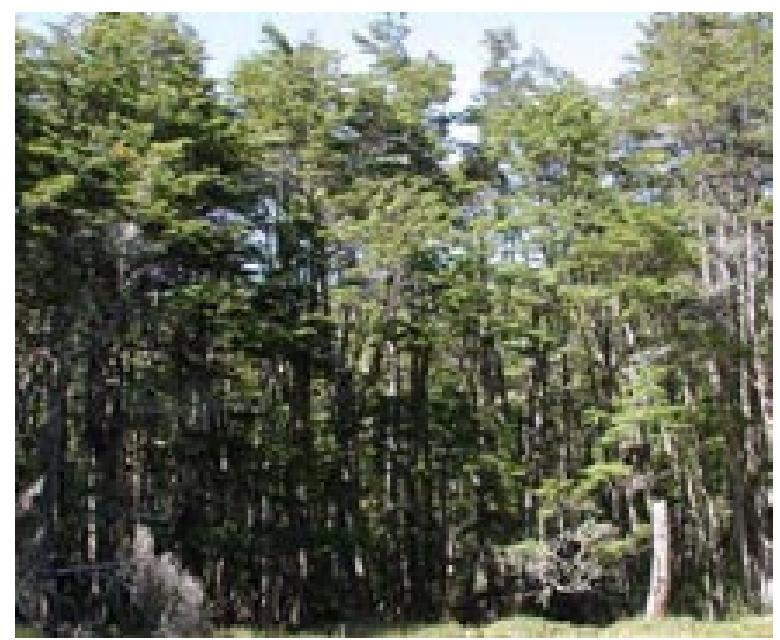

Fig. 5. Pure evergreen Nothofagus betuloides forest in Río Condor, Tierra del Fuego (Photo: A. Promis).

5.5) and not very fertile (Gerding \& Thiers 2002; Romanyà et al. 2005; Thiers \& Gerding 2007). Accumulation of huge layers of organic matter on the forest floor and large amounts of decaying wood have been described for this forest type in Tierra del Fuego (Gutiérrez et al. 1991). Most of the plant roots and nutrients are located in the bottom part of a thick raw humus layer, i.e., in a soil depth of only 4 to10 cm (Pisano 1977; Gutiérrez et al. 1991; Gerding \& Thiers 2002; Romanyà et al. 2005).

The $N$. betuloides forests form a very dense forest with few vascular plant species. Few individuals of the tree species D. winteri and Maytenus magellanica (Lam.) Hooker f. 1847 occur locally. There are few species in the shrub layer, which is dominated mainly by Berberis ilicifolia L.f. 1781. Less frequent and lower in cover are Empetrum rubrum Vahl ex Willd. 1806, Fuchsia magellanica Lam. 1788, Pernettya mucronata (L.f.) Gaudich. ex G.Don 1834, and Ribes magellanicum Poiret 1812. Vascular plant species of the ground flora are Adenocaulon chilense Less. 1831, Luzuriaga marginata (Banks \& Sol. ex Gaertner) Bentham \& Hooker f. 1883, Senecio acanthifolius Hombron \& Jacquinot 1846, Gunnera magellanica Lam. 1789, the ferns Blechnum magellanicum (Desv.) Mett. 1856, Blechnum penna-marina (Poiret) Kuhn 1868, Asplenium dareoides A.N. Desv. 1811, and filmy ferns, mostly Hymenophyllum pectinatum Cav. 1802, Hymenophyllum secundum Hooker \& Grev. 1831 and Hymenophyllum tortuosum 
Hooker \& Grev. 1831 (Pisano 1977; Moore 1983; Gajardo 1994). Worth mentioning is the dense cover of lower plants, dominating the forest floor, the decaying tree trunks, and as epiphytes the stems and branches of the trees. Characteristic mosses are Acrocladium auriculatum (Mont.) Mitt. 1869, Dendroligotrichum dendroides (Brid. ex Hedw.) Broth. 1905, Polytrichadelphus magellanicus (Hedw.) Mitt. 1859, Dicranoloma robustum (Hook. f. \& Wilson) Paris 1904, and Ptychomnion cygnisetum (Müll. Hal.) Kindb. 1888. The most common liverworts are Marchantia berteroana Lehm. \& Lindenb. 1834, Gakstroemia magellanica (Lam.) Trev. 1877, Schistochila lamellata (Hook.) Dumort. 1835, and Lepidozia filamentosa (Lehm. \& Lindenb.) Gottsche, Lindenb. \& Nees 1845 (McQueen 1976; Pisano 1977; Moore 1983). Worth mentioning are lichens like Cladonia sp. on the ground, and a large number of epiphytes.

A study of forest hydrology in a pure evergreen mature $N$. betuloides forest located in Tierra del Fuego showed that the canopy intercepts around $41 \%$ of the total rainfall $\left(779 \mathrm{~mm}^{2} \mathrm{ear}^{-1}\right)$. The direct throughfall was $59 \%$, and the stemflow averaged less than $0.1 \%$ of the total rainfall. The amount of water percolated was around $31 \%$ of the gross precipitation, and the water yield $33 \%$ (Frangi \& Ritcher 1994). The average mass of fallen coarse woody debris in stands on the Argentinean side of Tierra del Fuego has been measured at $52 \mathrm{Mg} \mathrm{ha}^{-1}$ (dry weight), with low decay rates for small branches $(\mathrm{k}=0.17)$. This might be related to the lower summer temperatures and saturated water conditions, which can reduce aeration of the laid logs on the ground (Frangi et al. 1997).

(2) Near the coast below ca. $200 \mathrm{~m}$ a.s.l., $D$. winteri is becoming a more regular component of the canopy, forming a mixed evergreen $N$. betuloides - D. winteri forest (Fig. 6). The precipitation ranges between 900-2,000 $\mathrm{mm}_{\text {year }}{ }^{-1}$, and there are low thermal amplitudes, indicating hyperoceanic climate (Pisano 1977). The soils are deep, but often poorly drained and waterlogged (Thiers \& Gerding 2007).

Between $8-12 \%$ of the trees are D. winteri, with isolated individuals of M. magellanica and Embothrium coccineum Forster \& Forster f. 1775. Floristically this association is very similar to the

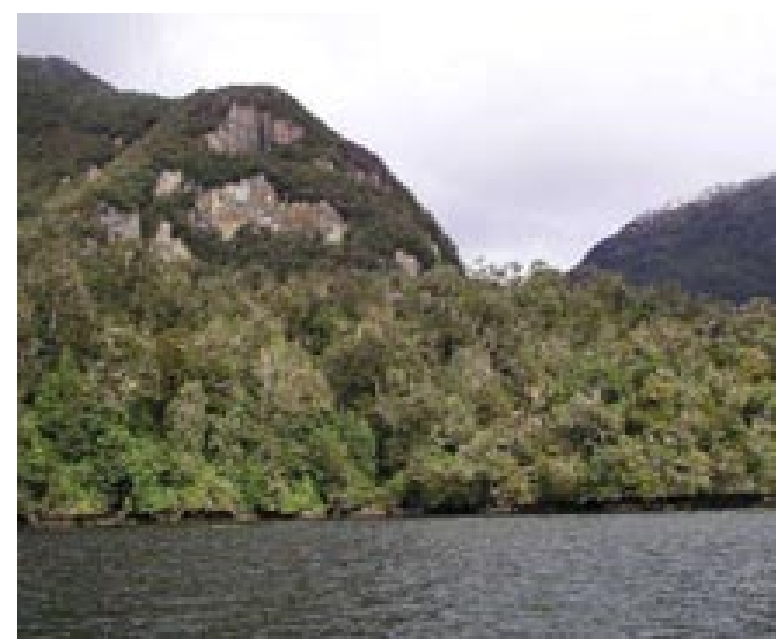

Fig. 6. Coastal mixed evergreen Nothofagus betuloides - Drimys winteri forest (Photo: G. Cruz).

pure evergreen $N$. betuloides forest. However, due to edaphic and climatic factors, the decomposition of litter is slow. The forest floors are covered by decomposed and decomposing tree trunks. These conditions facilitate the ferns $A$. dareoides, Cystopteris fragilis (L.) Bernh. 1806, Grammitis magellanica Desv. 1811, the lower plants and the filmy ferns mentioned above with the addition of Hymenophyllum ferrugineum Colla 1835, Hymenophyllum peltatum (Poiret) Desv. 1827, and Serpyllopsis caespitose (Gaudich.) C.Chr. 1910.

(3) At elevations below ca. $100 \mathrm{~m}$ a.s.l., the tree $P$. laetevirens joins the canopy, forming the coastal mixed evergreen $N$. betuloides $-D$. winteri $-P$. laetevirens forest. The precipitation ranges from around 1,500-4,000 $\mathrm{mm}_{\text {year }}{ }^{-1}$. The soils are often organic, with a deep accumulation of peat in the first horizon. The soil is covered by a thick litter layer of coarse woody debris in different stages of decay (Pisano 1977). Tree species such as D. winteri and $P$. laetevirens are very characteristic. The latter is a small tree up to $5 \mathrm{~m}$ tall. The ground vegetation is species poor, most dominant are mosses and liverworts on decaying wood.

(4) The mixed evergreen - deciduous N. betuloides $-N$. pumilio forest can be regarded as a transition between the evergreen and the deciduous Nothofagus forests (Fig. 7). N. betuloides dominates the more humid and poorly drained sites. With 


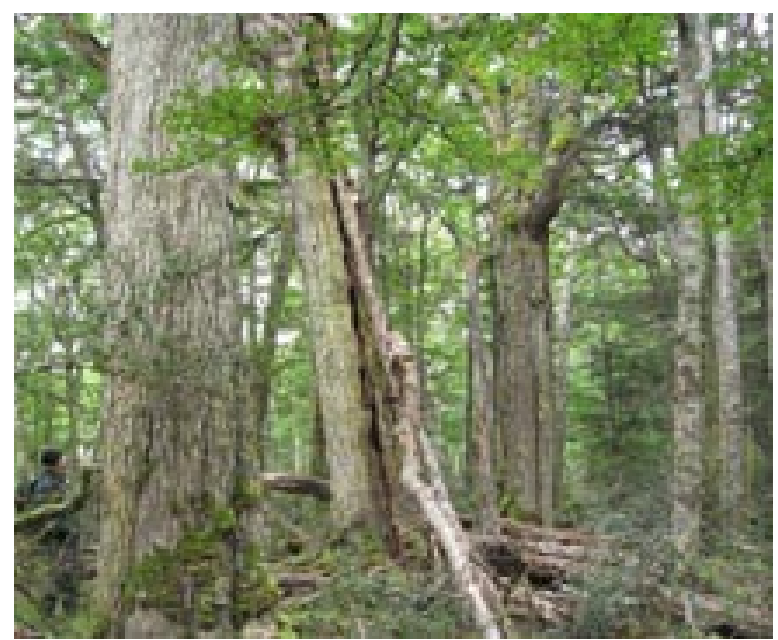

Fig. 7. Mixed evergreen - deciduous Nothofagus betuloides - Nothofagus pumilio forest (Photo: A. Reif).

decreasing rainfall the deciduous $N$. pumilio gains dominance and the transition to the deciduous forests is gradual. The soils are more fertile than those of the pure evergreen $N$. betuloides forest or the mixed evergreen $N$. betuloides $-D$. winteri forest (Thiers \& Gerding 2007). They are predominantly brown podsolic, with increased podsolisation in stands dominated by the deciduous $N$. pumilio (Pisano 1977). The tree species D. winteri and $M$. magellanica are present in low numbers. The coverage of the shrub understorey is low, dominated by $B$. ilicifolia and $P$. mucronata. There are fewer filmy ferns (Hymenophyllaceae spp.) and bryophyte species than in the forest types mentioned previously (Young 1972; McQueen 1976; Pisano 1977; Gajardo 1994; Luebert \& Pliscoff 2006).

(5) N. betuloides also can grow in the Magellan Mooreland, there being a minor species in shrubland dominated by Pilgerodendron uviferum (D.Don) Florin 1930, or as a low creeping shrub associated with Schoenus antarcticus (Hooker f.) Dusén 1900 and Carpha alpina var. schoenoides (Banks \& Sol. Ex Hooker f.) Kük. 1939 (Pisano 1977) and mosses including Sphagnum magellanicum Brid. 1798.

\subsubsection{Forest texture}

The structure of the forests of southern $\mathrm{Pa}$ tagonia and Tierra del Fuego is shaped principally by wind. Wind acts as an agent of both coarse and fine-scale disturbance. Storms can cause the blow-down of entire stands (Rebertus et al. 1997; Puigdefábregas et al. 1999). Wavelike patterns of gap formation have been documented for both pure $N$. betuloides and pure $N$. pumilio forests in Tierra del Fuego, and for mixed $N$. betuloides - $N$. pumilio forests, mostly on sites predisposed to wind disturbance (Rebertus \& Veblen 1993b; Rebertus et al. 1993; Puigdefábregas et al. 1999).

In most cases, windthrow of individual trees creates canopy gaps smaller than $200 \mathrm{~m}^{2}$ (Rebertus \& Veblen 1993a; Gutiérrez 1994). In pure N. betuloides stands, canopy openings can occur as interwoven gap complexes where discrete gaps are not apparent (Rebertus \& Veblen 1993a). Promis et al. (submitted) observed small canopy gaps (51 $\mathrm{m}^{2}$ ) in a pure, uneven-aged $N$. betuloides forest in Tierra del Fuego. In a mixed, uneven-aged $N$. betuloides $-N$. pumilio forest larger canopy gaps were found, with an average size of $107 \mathrm{~m}^{2}$ (Promis et al. submitted). In Tierra del Fuego a patch mosaic pattern has been observed in Nothofagus forests, with patches of younger trees neighbouring larger patches of old forest, forming multicohort stands (Gutiérrez et al. 1991).

\subsubsection{Forest dynamics and structure}

Disturbances of different frequencies and intensities on different sizes of areas are a major factor shaping the forest structures. The importance of coarse and fine-scale disturbances to the forest dynamics and structures of southern South American Nothofagus forests has been well summarised by Veblen et al. (1996) and Pollmann \& Veblen (2004).

\section{Coarse-scale disturbance}

Coarse-scale disturbances are generally necessary for the regeneration of Nothofagus at lower elevations and under a milder climate, where a number of shade-tolerant rain forest species are dominant, and a dense understorey competes with juveniles of Nothofagus.

Large-scale disturbance at higher elevations or latitudes can initiate regeneration patterns forming even-aged $N$. betuloides stands (Donoso \& Donoso 2007). Examples are the pure, even-aged secondary $N$. betuloides forest which established after a fire on the Argentinean side of Tierra del Fuego at the 
end of the 1950s (Martínez Pastur et al. 2002), or the pure, even-aged secondary forest of the coastal Chilean side of southern Patagonia and Tierra del Fuego, which recovered through natural succession after periods of colonisation during which the forests were selectively logged, burned and grazed.

\section{Fine-scale disturbance}

At higher elevations and at higher latitudes, where species richness is low, regeneration is less dependent on coarse-scale disturbance (Pollmann \& Veblen 2004). Here canopy gaps are more important for the regeneration of the Nothofagus species, e.g., in southern Patagonia and Tierra del Fuego. The wind-induced snapping and uprooting of trees were the most common types of mortality observed in a pure $N$. betuloides forest and in $N$. betuloides forest mixed with $N$. pumilio (Promis et al. submitted). In the pure $N$. betuloides forest 52 $\%$ of the tree-falls were snap and $30 \%$ uprooting. This appears to be characteristic of other Nothofagus dominated forests in South America. In the mixed $N$. betuloides $-N$. pumilio forest, however, the uprooting of trees was by far the most frequent cause of tree mortality, accounting for $70 \%$ of the tree-falls, compared to only $24 \%$ snapped trees. This largely corresponded with the findings from Tierra del Fuego (Rebertus \& Veblen 1993a).

The lower resistance to stem breakage and the prevalence of snapped trees in the evergreen $N$. betuloides forests might be related to crown dieback (Rebertus \& Veblen 1993b; Rebertus et al. 1993). An additional cause might be due to the abundance of the magellanic woodpecker (Campephilus magellanicus King. 1827). Its occurrence in forests in Tierra del Fuego has been related to the density of $N$. betuloides and the occurrence of snags (Vergara \& Schlatter 2004). Magellanic woodpeckers primarily consume the larvae of wood-boring coleopteras in large and decaying trees, and also drill holes in large and healthy trees to access the phloem sap (Schlatter \& Vergara 2005). Although not fatal in itself, the activity of the woodpecker may lead to secondary damage by diseases and insects. Insects and extreme climatic events may also reduce the vigour of trees, inducing partial crown mortality. This, too, facilitates fungal attacks and heart rot of the bole. The decaying standing deadwood enlarges the potential of trees suited for cavity creation by magellanic woodpeckers (Ojeda et al. 2007).

Both $N$. betuloides and $N$. pumilio can establish in small tree-fall canopy gaps (Veblen 1989; Rebertus \& Veblen 1993a; Gutiérrez 1994; Arroyo et al. 1996; Cuevas 2003; Fajardo \& de Graaf 2004; Cavieres \& Fajardo 2005). Juvenile trees are also released by the creation of these small-scale disturbances in the canopy (Veblen et al.1996), although the growth strategies of the species differ. The observation by Rebertus \& Veblen (1993a) that $N$. betuloides is more shade tolerant than $N$. pumilio has been proved in Tierra del Fuego by Promis et al. (submitted).

In the mixed evergreen $N$. betuloides $-D$. winteri forest at low elevations near the Tierra del Fuego coast, the $D$. winteri seedlings grow well under dense canopies and, after formation of gaps in the canopy, can respond faster than $N$. betuloides, sometimes even impeding the establishment of the latter (Rebertus et al. 1993a; Gutiérrez 1994; Veblen et al. 1996). Neither saplings nor pole stage $N$. betuloides are likely to be found where there are high numbers of $D$. winteri and $M$. magellanica in the understorey (Gutiérrez et al. 1991).

\section{Forest use in the past, the} present and the future

\subsection{The past}

The historical forest use has strongly influenced the present forest cover. In the Magellan Region of Chile (southern Patagonia), the history of forest use can been divided into four periods (Cruz et al. 2007b); (1) an indigenous period (10,000 B.C.1843); (2) a colonisation period (1843-1953); (3) an oil and industrial period (1953-1980); and (4) a forest management and industrial expansion period (1980-2004).

(1) Five different indigenous tribes inhabited Patagoni thousands of years before the arrival of the Spaniards ( $16^{\text {th }}$ century). The Strait of Magellan was inhabited by two nomadic tribes, the canoe aborigines (the Alacalufes or Kawéskar and the Yámanas or Yaganes) and the land aborigines (the Onas or Selk'man and the Haush or Manek'enk on the large island of Tierra del Fuego or Karukinká, and the Tehuelches or Patagones on the continent). 


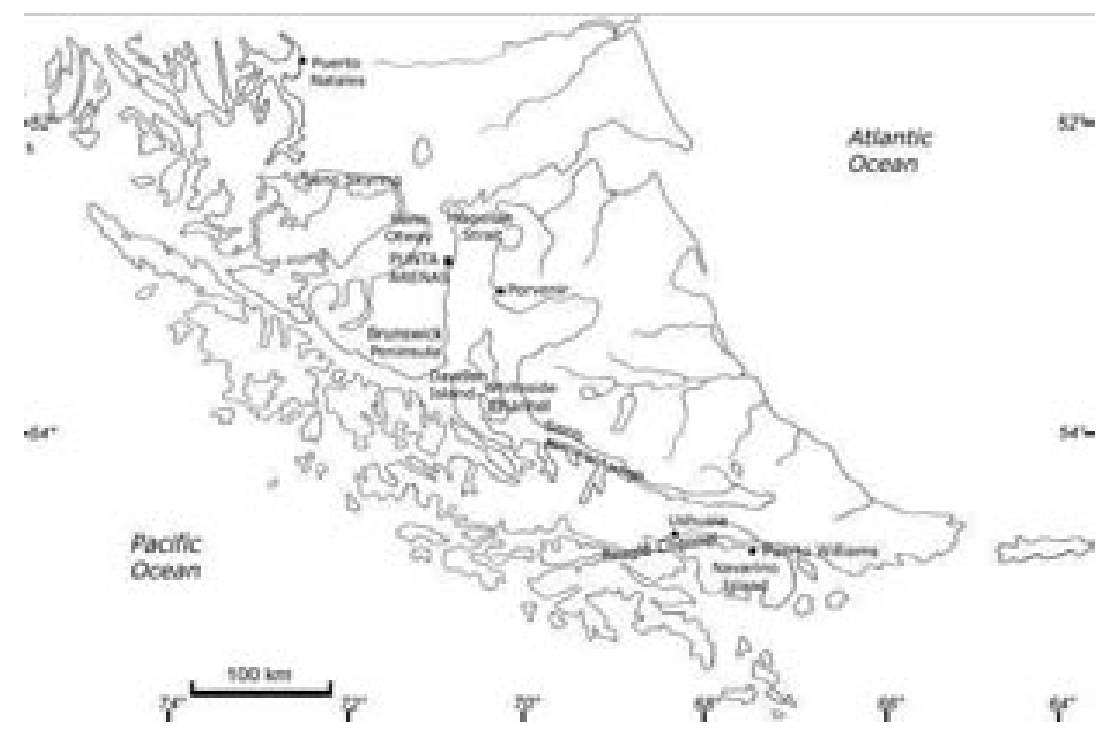

Fig. 8. Map of southern Patagonia and Tierra del Fuego showing the past locations of sawmills.

The indigenous people mainly used the forests to collect fungi and berries, and wood for fire, bows, arrows, domestic utensils and for constructing huts. Canoes were built with the bark of $N$. betuloides. There was also a spiritual attachment, with the Onas people believing that spirits inhabited the forests (Gusinde 1944; de Agostini, 1945, 1956; Martinic 1982, 1992; Vairo 1997).

(2) Harvesting of the N. betuloides forests began in 1843, when the Bulnes' Fort was built on the eastern side of the Brunswick Peninsula (Fig. 8), a consequence of the colonisation policies in southern Chile. In 1848 the city of Punta Arenas (Sandy Point) was founded. At this time wood became an important resource for construction and as fuel. The first sawmill with a hydropower system was established in Punta Arenas in 1861, and in 1875 steam power was introduced to the region in the form of locomotives. In the late $19^{\text {th }}$ century there were several sawmills located on the Brunswick Peninsula (Martinic 1992; Cruz et al. 2007b).

From the 1880s, many forests were converted to farmland and pasture through a process of logging and burning. In southern Patagonia and Tierra del Fuego, approximately 200,000-300,000 ha were transformed to pasture (Cruz \& Lara 1987; Cruz et al. 2007b).

In the late $19^{\text {th }}$ and early $20^{\text {th }}$ centuries the timber industry was centred on the Chilean side of southern Patagonia and Tierra del Fuego, but with the majority of the wood harvested destined for the Argentinean side of Patagonia and Tierra del Fuego, and the Falklands. New sawmills were established near forest dominated by $N$. betuloides, such as those situated on or near Dawson Island, the Whiteside Channel, the Almirantazgo Fjord, Navarino Island (Beagle Channel), the Otway Sound and Skyring Sound (Fig. 8). During this period N. betuloides provided around $80 \%$ of the timber traded. However, restrictions on the importation of wood put in place by the Argentinean government impeded the timber industry in Chile, with the lowest exportation rates recorded between 1951 and 1952 (Martinic 1992; Cruz et al. 2007b).

(3) In the middle of the $20^{\text {th }}$ century an intensive harvesting of the forests began on both the Chilean and the Argentinean (Gea-Izquierdo et al. 2004) sides of southern Patagonia. This coincided with the beginning of the oil and industrial period. At this time the forest industry concentrated on forests dominated by the deciduous $N$. pumilio, because oil exploration, and the related infrastructure, was frequently situated at locations near to these forests. The demand for wood from $N$. betuloides forests, which were located near urban areas and the coast, decreased. The harvested trees were logged selectively, with the best, largest and healthiest timber trees removed from the stands (known as 'floreo' in the region). Only the poor 
quality, badly shaped and unhealthy trees remained (Martínez Pastur et al. 2000; Klepeis \& Laris 2006; Cruz et al. 2007a). Many other stands were burned and converted to farmland.

The introduction of fossil fuels after the 1950 s as a new energy resource replaced the use of firewood. At that time $N$. betuloides accounted for around $15 \%$ of the total wood volume traded in the Chilean Patagonia and Tierra del Fuego (Cruz et al. 2007b).

(4) A new period of forest use in Chile began in the 1980s. Specific silvicultural methods for the management of the native forests were developed. It was demonstrated that $N$. betuloides forests in Chile could be managed employing either a selection or a shelterwood system (Donoso 1981). In reality, however, the stands were only rarely managed, with a small number of regeneration cuts made as part of a shelterwood system (Cruz et al. 2007a).

In the early 1990s a new, productive development of wood and forest management began. Wood chips were exported for a short time (19911997), and a furniture factory using solid wood was founded (Cruz et al. 2007b).

\subsection{The present}

At present the forest surface where $N$. betuloides participates is approximately $1,396,947$ ha in the Magellan Region in Chile, accounting for $53 \%$ of the total forest area. In terms of forest structure, $51 \%$ are old-growth, $6 \%$ are secondary growth, $9 \%$ represent a transition between mature and secondary growth, and $34 \%$ are 2 to $8 \mathrm{~m}$ tall shrubland (CONAF-CONAMA 1999).

A new period of forest conservation on private land began in 2004. In the 1990s the American Trillium Corporation purchased 625,000 ha on the Chilean and 185,000 ha on the Argentinean side of Tierra del Fuego. However, the firm failed in its attempts to establish a sustainable logging operation. Goldman Sachs, a global investment banking firm, acquired the loans and land, and finally donated the property to the Wildlife Conservation Society (WCS) in 2004 (Duncan 20061). At present, the property

\footnotetext{
${ }^{1}$ Duncan, F. 2006. Temperate Native Forests in Chile. Management, conservation and forest practices. Report to the J. W. Gottstein Memorial Trust.
}

on the Chilean side of Tierra del Fuego is managed by WCS as a private reserve. The principal aim of the Karukinka Reserve is to preserve the wildlife existing there, and to restore its ecosystems (Karukinka $2007^{2}$; WCS $2007^{3}$ ). This private reserve protects more than $20 \%$ of the Nothofagus betuloides forests of southern Patagonia and Tierra del Fuego in Chile (Arroyo et al. 1996).

Additionally, more than $49 \%$ of the N. betuloides forests of Chilean Patagonia and Tierra del Fuego are protected as State Protected Wild Areas (SNASPE) (CONAF-CONAMA 1999).

It can be estimated, that ca. 280,000 ha of pure $N$. betuloides forests and forests mixed with $N$. pumilio are suitable for timber production. $\mathrm{Be}-$ cause of logistical reasons, lack of ecological and silvicultural knowledge, and problems in the wood drying process, the use of these forests at present is marginal ( $<1 \%$ of wood production in 2004) (Cruz et al. 2007b). Sawn wood of $N$. betuloides is only produced in one big sawmill for the furniture production industry, consuming $<5 \%$ of the harvested timber (Cruz et al. 2007b).

\subsection{The future}

The $N$. betuloides forest area suitable for timber production in the Magellan Region of Chile has been estimated ca. 280,000 ha. Additionally, the forested area covered by the deciduous $N$. pumilio, the most important forest resource in southern Patagonia and Tierra del Fuego, has been estimated ca. 200,000 ha (Cruz et al. 2007b).

For the future development of a commercial forest industry, a system of sustainable forest management is required. This includes (1) increasing the managed forest area of stands dominated by $N$. betuloides, (2) improving current timber management (carrying out intermediate practices such as thinning), (3) incorporating the forests selectively logged in the past in silvicultural management schemes, (4) applying new silvicultural treatments in order to maintain the uneven-aged and multi-layer structure of the forest, based on an ecological understanding of the natural stand development, and including the

\footnotetext{
${ }^{2}$ Karukinka 2007. Karukinka is a new model for the conservation of biodiversity. Available from: http://www.karukinkanatural.cl/Karukinka/ index-english.htm (accessed 16.12.07).

${ }^{3}$ WCS 2007. Wildlife Conservation Society. Available from: http://www. wcs.org/sw-our_mission/institute (accessed 16.12.07).
} 
role of natural disturbances, providing the basis on which the forest may be managed as a renewable resource and trying to leave biological legacies in order to maintain a higher diversity and richness of species.

New studies of the ecology of the N. betuloides forests, their distribution, silviculture, wood properties, industrial yields, and also methods of drying have been carried out in the meantime (see Cruz \& Caldentey, 2007). The application of this new knowledge in combination with a diversification of the forest industry within the framework of sustainable forest management would allow the derivation of goods and services from forest landscapes, while certain levels of biodiversity and ecosystem processes could also be maintained.

\section{ACKNOWLEDGEMENTS}

The authors would like to thank the Chilean Project FONDEF D02I1080, the German Academic Exchange Service (DAAD) and the International 'Forestry in Transition' Ph.D. Programme of the Faculty of Forest and Environmental Sciences of the University of Freiburg. We are also grateful to the Programa de Bosques Patagónicos of the University of Chile. We also thank D. Butler-Manning and Christopher Guest for comments and help with the translation.

\section{LITERATURE CITED}

Armesto, J. J., I. Casassa \& O. Dollenz 1992. Age structure and dynamics of Patagonian beech forests in Torres del Paine National Park, Chile. Vegetatio, 98: 13-22.

Arroyo, M. T. K., C. Donoso, R. E. Murúa, E. E. Pisano, R. P. Schlatter \& I. A. Serey 1996. Toward an Ecologically Sustainable Forestry Project. Concepts, analysis and recommendations. Departamento de Investigación y Desarrollo, Universidad de Chile, Santiago, Chile.

Báez, P., M. Riveros \& C. Lehnebach 2002. Viability and longevity of pollen of Nothofagus species in south Chile. New Zealand Journal of Botany, 40: 671-678.

Cavieres, L. A. \& A. Fajardo 2005. Browsing by guanaco (Lama guanicoe) on Nothofagus pumilio forest gaps in Tierra del Fuego, Chile. Forest Ecology and Management, 204: 237-248.

CONAF-CONAMA 1999. Catastro y Evaluación de Recursos Vegetacionales Nativos de Chile. Informe Regional Duodécima Región. Santiago, Chile.

Cruz, G. \& A. Lara 1987. Vegetación del Área de Uso Agrpecuario de la XII Región, Magallanes y de la Antártica Chilena. INIA, Intendencia de la XII Región.

Cruz, G, \& J. Caldentey 2007. Caracterización, Silvicultura y Uso de los Bosques de Coihue deMagallanes (Nothofagus betuloides) en la XII Región de Chile. Facultad de Ciencias Forestales, Universidad de Chile, Santiago, Chile.

Cruz, G., R. Caprile, A. Promis \& G. Cabello 2007a. Structural and biometric characterization of Nothofagus betuloides production forests in the Magellan Region, Chile. Journal of Sustainable Forestry, 24 (2/3): 123-140.

Cruz, G., M. Rosenfeld, G. Cabello \& F. Hidalgo 2007b. Uso de los bosques de Coihue de Magallanes, pp. 100-114. En: G. Cruz \& J. Caldentey (eds.), Caracterización, Silvicultura y Uso de los Bosques de Coihue de Magallanes (Nothofagus betuloides) en la XII Región de Chile. Facultad de Ciencias Forestales, Universidad de Chile, Santiago, Chile.

Cuevas, J. G. 2003. Gap characteristics in relation to forest structure and implications for southern beech forest dynamics. Canadian Journal of Forest Research, 33: 1915-1922.

Darwin, C. 1839. Journal and remarks, 1832-36. In: R. Fitzroy (ed.), Narrative of the Suveying Voyagesof His Majesty's Ships Adventure and Beagle between the Years 1826 and 1836. Vol. III. Henry Colburn, London.

De Agostini, A. 1945. Andes Patagónicos. Viajes de exploración a la Cordillera Patagónica Austral. Buenos Aires, Argentina.

De Agostini, A. 1956. 30 Años en Tierra del Fuego. Editorial Peuser, Buenos Aires, Argentina.

Dimitri, M. J. 1972. La Región de los Bosques Andino-Patagónicos. Sinopsis General. Colección Científica del INTA, Buenos Aires, Argentina. 
Donoso, C. 1981. Tipos Forestales de los Bosques Nativos de Chile. Documento de Trabajo №38. Investigación y Desarrollo Forestal (CONAF/PNUD/FAO), Santiago, Chile.

Donoso, C. \& J. Atienza 1983. Hibridación natural entre especies de Nothofagus siempreverdes en Chile. Bosque, 5 (1): 21-34.

Donoso, C. \& P. Donoso 2007. Nothofagus betuloides (Mirb.) Oerst. Coigüe de Magallanes, Ouchpaya (onas), Guindo (zona Austral), Coigüe Colorado (Tierra del Fuego), pp. 411-422. En: C. Donoso (ed.), Las Especies Arbóreas de los Bosques Templados de Chile y Argentina. Autoecología. Marisa Cuneo Ediciones, Valdivia, Chile.

Donoso, C., A. Premoli \& P. Donoso 2004. Variación en Nothofagus siempreverdes sudamericanos, pp. 189-213. En: C. Donoso, A. Premoli, L. Gallo \& R. Ipinza (eds.), Variación Intraespecífica en Especies Arbóreas de los Bosques Templados de Chile y Argentina. Editorial Universitaria, Santiago, Chile.

Fajardo, A. \& R. de Graaf 2004. Tree dynamics in canopy gaps in old-growth forests of Nothofagus pumilio in southern Chile. Plant Ecology, 173: 95-105.

Frangi, J. L. \& L. L. Richter 1994. Balabces hídricos de bosques de Nothofagus de Tierra del Fuego, Argentina. Revista de la Facultad de Agronomía , La Plata, 70: 65-79.

Frangi, J. L., L. L. Richter, M. D. Barrera \& M. Aloggia 1997. Decomposition of Nothofagus fallen woody debris in forests of Tierra del Fuego, Argentina. Canadian Journal of Forest Research, 27: 1095-1102.

Gajardo, R. 1994. La Vegetación Natural de Chile. Clasificación y distribución geográfica. Editorial Universitaria, Santiago, Chile. 165 p.

Gea-Izquierdo, G., G. Martínez Pastur, J. M. Cellini \& M. V. Lencinas 2004. Forty years of silvicultural management in southern Nothofagus pumilio primary forests. Forest Ecology and Management, 201: 335-347.

Gerding, V. \& O. Thiers 2002. Characterization of soils of Nothofagus betuloides (Mirb.) Blume forests, in Tierra del Fuego. Chile. Revista Chilena Historia Natural, 75: 819-833.

Godley, E. J. 1960. The botany of southern Chile in relation to New Zealand and the Subantarctic.
Proceedings of the Royal Society of London, Series B, 152: 457-475.

Gusinde, M. 1944. Urmenschen im Feuerland: vom Forscher zum Stammesmitglied. Paul Zsolnay, Berlin, Germany.

Gutiérrez, E. 1994. Els boscos de Nothofagus de la Terra del Foc com a paradigma de dinàmica successional del no-equilibri. Treballs de la Societat Catalana de Biologia, 45: 93-121.

Gutiérrez, E., V. R. Vallejo, J. Romaña \& J. Fons 1991. The subantarctic Nothofagus forests of Tierra del Fuego: distribution, structure and production. Oecologia Aquatica, 10: 351-366.

Hill, R. S. \& M. E. Dettmann 1996. Origin and diversification of the genus Nothofagus; pp. 11-24. In: T.T. Veblen, R. S. Hill \& J. Read (Eds.), The Ecology and Biogeography of Nothofagus Forests. Yale University Press, New Haven, USA.

Hill, R. S. \& G. J. Jordan 1993. The evolutionary history of Nothofagus (Nothofagaceae). Australian Systematic Botany, 6(2): 111-126.

Ibarra, M., J. Caldentey \& F. Hidalgo 2007. Antecedentes generales de la especie, pp. 3-11. En: G. Cruz \& J. Caldentey (eds.), Caracterización, Silvicultura y Uso de los Bosques de Coihue de Magallanes (Nothofagus betuloides) en la XII Región de Chile. Facultad de Ciencias Forestales, Universidad de Chile, Santiago, Chile.

Jordan, G. J. \& R. S. Hill 1999. The phylogenetic affinities of Nothofagus (Nothofagaceae) leaf fossils based on combined molecular and morphological data. International Journal of Plant Sciences, 160(6): 1177-1188.

Klepeis, P. \& P. Laris 2006. Contesting sustainable development in Tierra del Fuego. Geoforum, 37: 505-518.

Luebert, F. \& P. Pliscoff 2006. Sinópsis Bioclimática $y$ Vegetacional de Chile. Editorial Universitaria, Santiago, Chile.

Manos, P. S. 1997. Systematics of Nothofagus (Nothofagaceae) based on rDNA spacer sequences (ITS): Taxonomic congruence with morphology and plastid sequences. American Journal of Botany, 84: 1137-1155.

Manso, M., M. Ibarra, L. Nutto \& G. Becker 2007. Características técnológicas y usos de la ma- 
dera, pp. 75-99. En: G. Cruz \& J. Caldentey (eds.), Caracterización, Silvicultura y Uso de los Bosques de Coihue de Magallanes (Nothofagus betuloides) en la XII Región de Chile. Facultad de Ciencias Forestales, Universidad de Chile, Santiago, Chile.

Martínez Pastur, G., M. E. Arena \& C. Fernández 1994. Nota sobre la influencia del ácido giberélico y del nitrato de potasio en la germinación de semillas de Nothofagus betuloides (Mirb.) Oerst. Investigación Agraria. Sistemas y Recursos Forestales, 3(1): 83-89.

Martínez Pastur, G., J. M. Cellini, P. L. Peri, R. F. Vukasovic \& M. C. Fernández 2000. Timber production of Nothofagus pumilio forests by a shelterwood system in Tierra del Fuego (Argentina). Forest Ecology and Management, 134: 153-162.

Martínez Pastur, G., J. M. Cellini, M. V. Lencinas, R. F. Vukasovic, P. L. Peri \& S. Donoso 2002. Response of Nothofagus betuloides (Mirb.) Oerst. to different thinning intensities in Tierra del Fuego, Argentina. Interciencia, 27: 679-685.

Martinic, M. 1982. La Tierra de los Fuegos. Historia, geografía, sociedad, economía. Artegraf Ltda., Punta Arenas, Chile.

Martinic, M. 1992. Historia de la Región Magallánica. Volúmenes I-II. Universidad de Magallanes, Punta Arenas, Chile.

McQueen, D. R. 1976. The ecology of Nothofagus and associated vegetation in South America. Part I. Vegetation and soils in Southern Patagonia and Tierra del Fuego. Tuatara, 22(1): 38-68.

Moore, D. 1983. Flora of Tierra del Fuego. Anthony Nelson, England, Missouri Botanical Garden, USA.

Oberdorfer, E. 1960. Pflanzensoziologische Studien in Chile: Ein Vergleich mit Europa. Flora et Vegetatio Mundi, 2: 1-208.

Ogden, J., G. H. Stewart \& R. B. ALLEN 1996. Ecology of New Zealand Nothofagus forests, pp. 25-82. In: T. T. Veblen, R. S. Hill \& J. Read (eds.), The Ecology and Biogeography of Nothofagus Forests. Yale University Press, New Haven, USA.

Ojeda, V. S., M. L. Suarez, \& T. Kitzberger 2007. Crown dieback events as key processes creating cavity habitat for magellanic woodpeckers. Austral Ecology, 32: 436-445.

Pérez, V. 1983. Manual de Propiedades Físicas y Mecánicas de Maderas Chilenas. Documento de Trabajo No37. Investigación y Desarrollo Forestal (CONAF/ PNUD/FAO), Santiago, Chile.

Pisano, E. 1977. Fitogeografía de Tierra del Fuego - Patagonia Chilena. I Comunidades vegetales entre las latitudes $52^{\circ}$ y $56^{\circ} \mathrm{S}$. Anales Instituto Patagonia (Chile), 8: 121-250.

Pisano, E. 1978. Establecimiento de Nothofagus betuloides (Mirb.) Blume (Coigüe de Magallanes) en un valle en proceso de desglaciación. Anales del Instituto de la Patagonia, 9: $107-128$.

Pisano, E. 1981. Bosquejo fitogeográfico de FuegoPatagonia. Anales Instituto Patagonia (Chile). 12:159-171.

Pisano, E. 1997. Los bosques de Patagonia Austral y Tierra del Fuego Chilenas. Anales Instituto Patagonia, Serie Cs. Nat. (Chile). 25: 9-19.

Pollmann, W. 2005. A long-term record of Nothofagus dominance in the southern Andes, Chile. Austral Ecology, 30: 91-102.

Pollmann, W. \& T. T. Veblen 2004. Nothofagus regeneration dynamics in South-Central Chile: a test of a general model. Ecological Monographs, 74: 615-634.

Promis, A., S. Gärtner, A. Reif \& G. Cruz (submitted): Natural disturbances and tree development processes in two temperate forest types dominated by Nothofagus betuloides in Tierra del Fuego. Austral Ecology.

Puigdefábregas, J., F. Gallart, O. Biaciotto, M. Allogia \& G. del Barrio 1999. Banded vegetation patterning in a subantarctic forest of Tierra del Fuego, as an outcome of the interaction between wind and tree growth. Acta Oecologica, 20: 135-146.

Read, J. \& M. J. Brown 1996. Ecology of Australian Nothofagus forests, pp. 131-181. In: T. T. Veblen, R. S. Hill \& J. Read (eds.), The Ecology and Biogeography of Nothofagus Forests. Yale University Press, New Haven, USA.

Read, J. \& G. S. Hope 1996. Ecology of Nothofagus forests of New Guinea and New Caledonia, pp. 200-256. In: T. T. Veblen, R. S. Hill \& J. 
Read (eds.), The Ecology and Biogeography of Nothofagus Forests. Yale University Press, New Haven, USA.

Rebertus, A. J. \& T. T. Veblen 1993a. Structure and tree-fall gap dynamics of old-growth Nothofagus forests in Tierra del Fuego, Argentina. Journal of Vegetation Science, 4: 641-654.

Rebertus, A. J. \& T. T. Veblen 1993b. Partial wave formation in old-growth Nothofagus forests on Tierra del Fuego, Argentina. Bulletin of the Torrey Botanical Club, 120: 461-470.

Rebertus, A. J., T. T. Veblen \& T. Kitzberger 1993. Gap formation and dieback in Fuego-Patagonian Nothofagus forests. Phytocoenologia, 23: 581-599.

Rebertus, A. J., T. Kitzberger, T. T. Veblen \& L. M. Roovers 1997. Blowdown history and landscape patterns in the Andes of Tierra del Fuego, Argentina. Ecology, 78: 678-692.

Rodríguez, R. \& M. Quezada 2003. Fagaceae, pp. 64-76. En: C. Marticorena \& R.

Rodríguez (eds.), Flora de Chile Vol. 2 (2) Berberidaceae - Betulaceae. Universidad de Concepción, Chile.

Roig, F., J. Anchorena, O. Dollenz, M. Faggi \& E. Méndez 1985. Las comunidades vegetales de la transecta botánica de la Patagonia Austral, pp. 350-519. En: O. Boelcke, M. Moore \& F. Roig (eds.), Transecta Botánica de la Patagonia Austral. Consejo Nacional de Investigaciones Científicas y Técnicas (Argentina), Instituto de la Patagonia (Chile), Royal Society (Gran Bretaña), Buenos Aires, Argentina.

Romanyà, J., J. Fons, T. Sauras-Yera, E. Gutiérrez \& V. R. Vallejo 2005. Soil-plant relationships and tree distribution in old growth Nothofagus betuloides and Nothofagus pumilio forests of Tierra del Fuego. Geoderma, 124: 169-180.

Schlatter, R. P. \& P. Vergara 2005. Magellanic woodpecker (Campephilus magellanicus) sap feeding and its role in the Tierra del Fuego forest bird assemblage. Journal of Ornithology, 146: 188-190.

Schmithüsen, J. 1956. Die räumliche Ordnung der chilenischen Vegetation. Bonner Geographische Abhandlungen, 17: 1-86.
Skottsberg, C. 1910. Botanische Ergebnisse der Schwedischen Expedition nach Patagonien und dem Feuerlande 1907-1909. I. Übersicht über die wichtigsten Pflanzenformationen Südamerikas S. von $41^{\circ}$, ihre geographische Verbreitung und Beziehungen zum Klima. Kungl. Suenska Vetenskapsakademiens Handlingar, 46(3): 1-28.

Squeo, F. \& M. Cabrera 1995. Ecofisiología Vegetal. Comité Científico Proyecto Río Cóndor. Estudio de Línea Base. Informe del Subproyecto 94-13.

Swenson, U., R. S. Hill, \& S. McLoughlin 2001. Biogeography of Nothofagus supports the sequence of Gondwana break-up. Taxon, 50: 1025-1041.

Thiers, O. \& V. Gerding 2007. Variabilidad topográfica y edáfica en bosques de Nothofagus betuloides (Mirb) Blume, en el suroeste de Tierra del Fuego. Chile. Revista Chilena Historia Natural, 80: 201-211.

Tuhkanen, S.I. 1992. The climate of Tierra del Fuego from a vegetation geographical point of view and its ecoclimatic counterparts elsewhere. Acta Botanici Fennici 145: 1-64.

Tuhkanen, S., I. Kuokka, J. Hyvönen, S. Stenroos \& J. Niemelä 1989-1990. Tierra del Fuego as a target for biogeographical research in the past and present. Anales Instituto Patagonia, Serie Cs. Nat. (Chile). 19(2): 5-107.

Vairo, C. 1997. Los Yamana. Nuestra única tradición naval marítima autóctona. Zagier \& Urruty, Buenos Aires, Argentina.

Van Royen, P. 1983. The Alpine Flora of New Guinea 4. Cramer, Vaduz.

Veblen, T. T. 1989. Nothofagus regeneration in tree-fall gaps in northern Patagonia. Canadian Journal of Forest Research, 19: 365-371.

Veblen, T. T., F. M. Schlegel \& J. V. Oltremari 1983. Temperate broad-leaved evergreen forests of South America, pp. 5-31. In: Ovington, J. D. (Ed.), Temperate Broad-leaved Evergreen Forests. Elsevier, Amsterdam, The Netherlands.

Veblen, T. T., C. Donoso, T. Kitzberger \& A. J. Rebertus 1996. Ecology of Southern Chilean and Argentinean Nothofagus forests, pp. 293-353. In: T. T. Veblen, R. S. Hill \& J. 
Read (Eds.), The Ecology and Biogeography of Nothofagus Forests. Yale University Press, New Haven, USA.

Vergara, P. \& R. P. Schlatter 2004. Magellanic woodpecker (Campephilus magellanicus) abundance and foraging in Tierra del Fuego, Chile. Journal of Ornithology, 145: 343-351.
Wardle, J. A. 1984. The New Zealand beeches. Ecology, utilization and management. New Zealand Forest Service, Christchurch, New Zealand. Young, S. 1972. Subantarctic rain forest of Magellanic Chile: Distribution, composition, and age and growth rate studies of common forest trees. Antarctic Research Series. U.S., 20: 307-322. 
A. PROMIS et al. 